\title{
THE MICROSTRUCTURE AND PROPERTIES OF MAGNESIUM ALLOYS AFTER DEFORMATION PROCESS WITH THE USE OF KOBO METHOD
}

\author{
Iwona BEDNARCZYK \\ Silesian University of Technology, Faculty of Materials Engineering and Metallurgy, Katowice, Poland, EU, \\ iwona.bednarczyk@polsl.pl
}

https://doi.org/10.37904/metal.2019.818

\begin{abstract}
The article presents tests results of metalforming of magnesium alloy. Materials for tests were ingots sized $\phi$ $40 \times 90 \mathrm{~mm}$ from magnesium alloys marked with symbol WE43, AZ61. Before the shaping process the ingots underwent heat treatment. As a result of conduction of the deformation processes there were rods achieved with diameter of 8 and $6 \mathrm{~mm}$. Static tensile test was conducted in room temperature (RT), $300^{\circ} \mathrm{C}$ and $350^{\circ} \mathrm{C}$. With the use of light and electron microscopy techniques the changes which occurred in the microstructure of magnesium alloys in initial condition and after plastic deformation (classic extrusion, KoBo method extrusion) were described. Analysis of microstructure was completed with the quantitative analysis with the use of Metilo program. Measurement of grain size was conducted with the use of surface method based on the images registered by light and scanning microscopes.
\end{abstract}

Keywords: Magnesium alloys, method SPD, static tensil test, average equivalent diameter of grains, microstructure

\section{INTRODUCTION}

Magnesium alloys are the lightest metal light materials for industrial application with increasing leeds due to their low density, high specific strength, good damping characteristics nad stable machinability. As the lightest structural metal, Mg alloys especially Mg-Al based alloys (AZ31, AZ61, AZ91) are widely used in fields of automotive, aerospace and telecommunication industries. Second group of alloys is a group Mg-Y-Re-Zr which includes alloy WE43 which is plastically formed mostly in the process of extrusion. This alloy is approved for application in construction elements for aviation industry mainly because it does not change its resistance properties up a temperature of $250^{\circ} \mathrm{C}$ [1-5]. However in view of the structure of hexagonal close-packing lattice magnesium exhibits less independent slip systems at room temperature and its alloys still show poor ductility and low strength, which greatly restrict their widespread applications. According to Hall-Petch relationship, grain refinement is an effective metod to enhance strength and ductility of magnesium alloy.Therefore various methods have been developend to improve the mechanical properties of magnesium alloys via grain refinement turing the last two decades. Considerable interest has recently developer regarding the potential for the processing rusing severe plastic deformation (SPD) of Mg alloys [4]. The SPD methods are based on a concept of transformation of micrometric grain structure of conventional metallic materials into nanometric structure by transforming the dislocation structure which is formed as a result of plastic deformation. Those methods are characterised with periodicity or repeatability of the deformations. Despite many advantages those methods are characterised with non-uniform $[2,10]$. They give possibilities of material deformation as a result of application of additional, periodically changeable impact on the deformation process (drawing, forging, rolling, extrusion) [9]. As it is confirmed in literature [9-11] the SPD methods were applied to shape the structure and properties of materials such as: $\mathrm{Cu}, \mathrm{Al}$, aluminium alloys, steel types for automotive industry IF, DP and conventional magnesium alloys (AZ61, WE43, AZ31). The paper presents the process of shaping conducted with the use of extrusion with KOBO method included among the unconventional ways of plastic shaping of magnesium alloys WE43, AZ61 with the use of Severe Plastic Deformation (SPD). The method is based on the application of the additional reversible torsion of die with defined angle and determined 
frequency. Deformation conducted with the use of die torsion leads to creation of viscoplastic character of material flow. All the conducted operations with the use of KoBo method allow for significant reduction of energy consumption of the process through decrease of the force needed to deform the metal, sometimes even $50 \%$ less than in conventional methods of deformation. Besides, they enable the achievement of bigger plastic deformations by smaller deformation forces and at the same time a bigger throughput of the material. The results of the tests which have been conducted so far show that there is a possibility of shaping magnesium alloys with the use of very big deformations without the necessity of prior heating of the charge. Additionally, the achieved products are characterised with good resistance properties and good plastic properties $[4,5,9]$. After the extrusion process with KoBo method, an analysis of the microstructure and properties was conducted for alloys AZ61, WE43. Static tensile tests were performed in elevated temperatures: $R T, 300,350^{\circ} \mathrm{C}$

\section{MATERIAL AND TESTED}

Material for tests was from AZ61, WE43 alloys after casting and heat treatment in temperature of $400{ }^{\circ} \mathrm{C}$ for 40 minutes cooled with furnace. Chemical compositions of the tested alloys is presented in Table 1.

Table 1 Chemical compositions of magnesium alloys (mas.\%)

\begin{tabular}{|c|c|c|c|c|c|c|c|}
\hline \multirow{2}{*}{ AZ61 } & $\mathrm{Al}$ & $\mathrm{Zn}$ & $\mathrm{Mn}$ & $\mathrm{Si}$ & $\mathrm{Fe}$ & $\mathrm{Mg}$ & $\mathrm{Ni}$ \\
\cline { 2 - 8 } & 5.92 & 0.49 & 0.15 &., 037 & 0.007 & 93.33 & 0.066 \\
\hline
\end{tabular}

\begin{tabular}{|c|c|c|c|c|c|c|c|c|c|}
\hline \multirow{2}{*}{ WE43 } & $\mathrm{Mg}$ & $\mathrm{Y}$ & $\mathrm{RE}$ & $\mathrm{Zr}$ & $\mathrm{Zn}$ & $\mathrm{Si}$ & $\mathrm{Cu}$ & $\mathrm{Ag}$ & $\mathrm{Fe}$ \\
\cline { 2 - 9 } & 90.2 & 4 & 3 & 0.54 & 0.03 & 0.01 & 0.01 & 0.01 & 0.002 \\
\hline
\end{tabular}

Next, the ingots were subject to annealing in temperature of $400{ }^{\circ} \mathrm{C}$ and time of annealing of 40 min and cooling in air. In the next stage the alloys were directly extruded with the KoBo method in room temperature without prior heating with the shift speed of inverted die of $0.33 \mathrm{~mm} / \mathrm{s}$ and die torsion angle of $\pm 8^{\circ}$ and frequency of $5 \mathrm{~Hz}$ (Figure 1). Rods with diameter of $\phi 8 \mathrm{~mm}$ and $6 \mathrm{~mm}$ were achieved as a result of extrusion and the processing degree $\lambda$ was calculated for them and equalled 100. The material was intensively cooled with water at the press throat outlet.
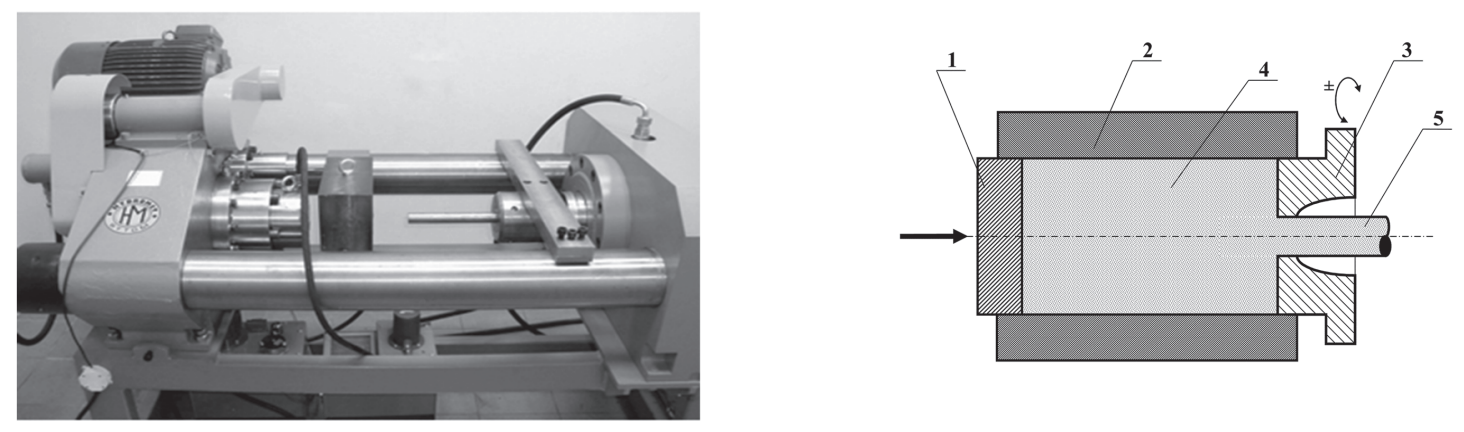

Figure 1 KoBo extrusion press at AGH University of Technology, Kraków, Poland, 1-punch, 2- container, 3- cyclic rotated die with grooves on face area surface, 4 - extruded material, 5 - charge/product [4]

Static tensile test was conducted on a Zwick/Roll machine in temperature $\mathrm{RT}, 300{ }^{\circ} \mathrm{C}, 350^{\circ} \mathrm{C}$ with deformation

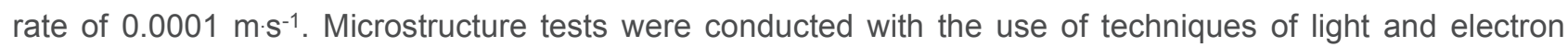
microscopy. Analysis of microstructure was completed with the quantitative analysis with the use of Met-ilo 
program [8]. Measurement of grain size was conducted with the use of surface method based on the images registered by light and scanning microscopes.

\section{RESULTS OF TESTS}

The microstructures of tested magnesium alloys after the process of casting and heat treatment are presented in Figure 2. Results of quantitative characterization AZ61, WE43 alloys are presented in Table 2, and Table 3. Magnesium alloys after casting process and heat treatment are characterised with coarse-grained structure with varied grain sizes (Figure 1). In microstructure of alloys WE43 and AZ61 there were precipitations on grain boundaries found with varied shapes and morphology (Figure 1). Figure 2 presents microstructures of alloys WE43 and AZ61 after deformation with KoBo method. Application of this deformation method allowed for achievement of significant grain refinement in the microstructure of both alloys WE43 and AZ61 (Figure 2). For alloys WE43 and AZ61 after extrusion with KoBo method the degree of processing from diameter of 40 $\mathrm{mm}$ to diameter of $8 \mathrm{~mm}$ was not so big and that is why small refinement of microstructure was achieved in comparison with initial condition Figures 1, 2a-b (Tables 2, 3). That is why a comparable grain size in microstructure of alloy AZ61 was achieved in initial condition and equalled $d=27 \mu \mathrm{m}$, and after extrusion with KoBo method $d=23 \mu \mathrm{m}$ (AZ61) (Table 2). The biggest grain refinement was achieved in microstructure of alloys WE43, AZ61 (rod with diameter of $6 \mathrm{~mm}$ ) where the grains with diameters of $1 \mu \mathrm{m}$ (WE43) and $10 \mu \mathrm{m}$ (AZ61) were achieved (Tables 2, 3). Microstructure of alloy WE43 after extrusion with KOBO method is characterised with a structure with more equiaxial grains than the structure after casting process which is visible in the classic shape factor (after deformation the shape factor equalled - 0.73 , after casting process and heat treatment - 0.58). Grain surface area is between 0.045 and $2.894 \mu \mathrm{m}^{2}$ and most grains matches the lower sizes in this range. It can be read from grain-size distribution that such value after extrusion process with KOBO method had 100 times decreased in comparison with initial state (after casting $99 \mu \mathrm{m} 2$, after deformation $0.51 \mu \mathrm{m}^{2}$ ) (Table 3). Also in case of alloy AZ61 which underwent the process of KOBO method the conducted quantitative analysis confirmed that the structure underwent refinement and the results equal respectively: mean grain diameter $d=27 \mu \mathrm{m}$ and de-creased in comparison with initial state $(d=10 \mu \mathrm{m})$ whereas the mean surface area of grain plane section equalled $30 \mu \mathrm{m}^{2}$. Surface area distribution of grain plane section shows that the parameter after extrusion with KoBo method was more than halved in comparison with the initial state (after casting process $70 \mu \mathrm{m}^{2}$, after deformation process $30 \mu \mathrm{m}^{2}$ ) [9].

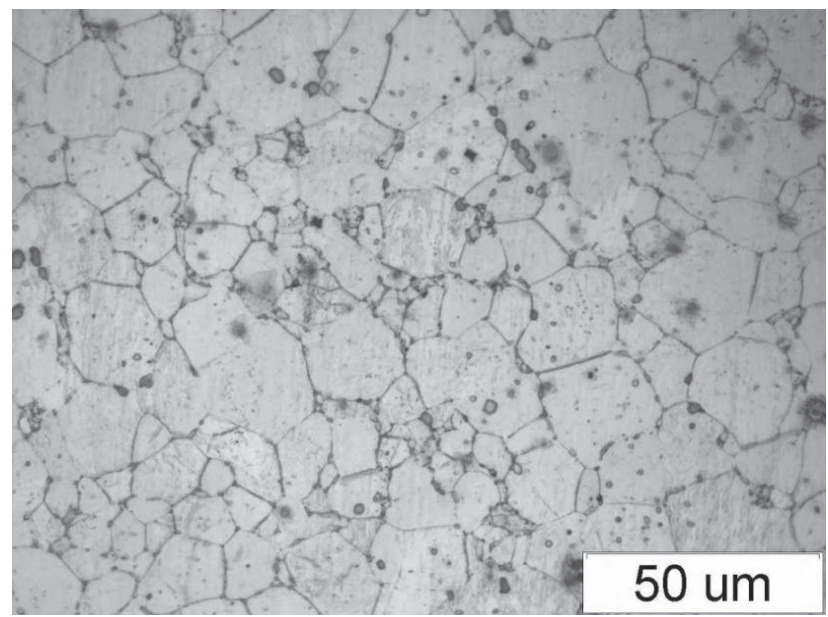

a)

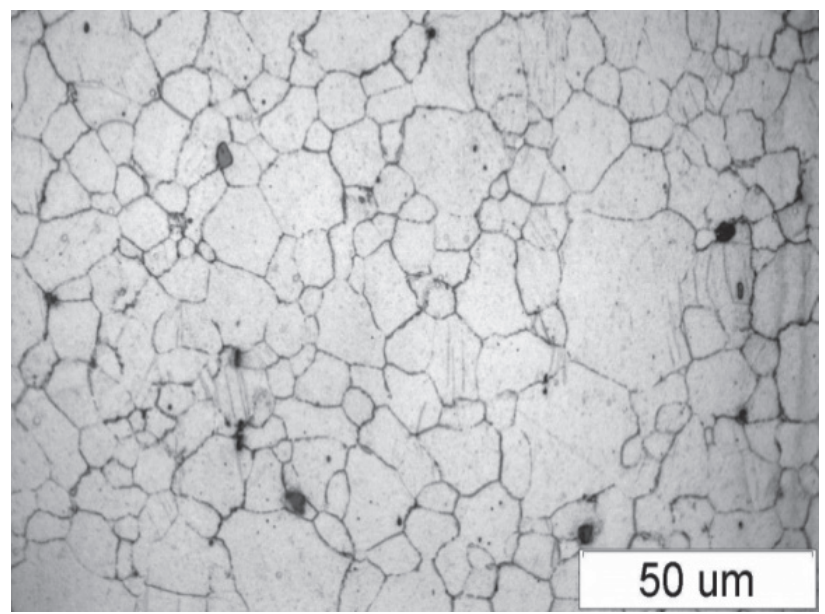

b)

Figure 2 Microstructure magnesium alloys: a) WE43, b) AZ61 after casting and heat treatment processes 
WE43

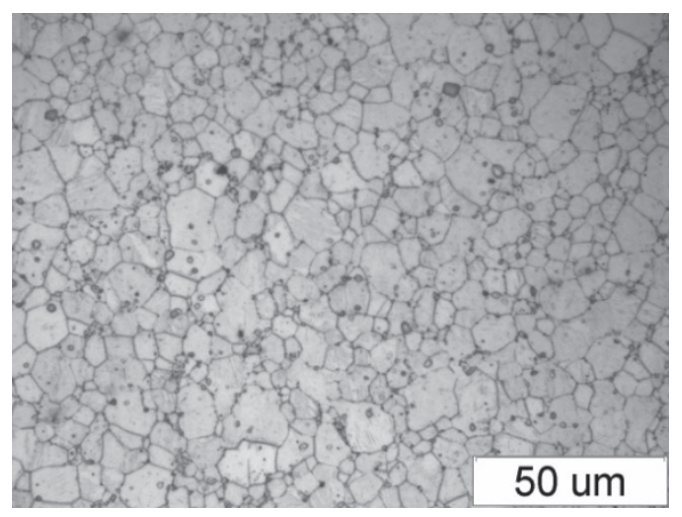

a)

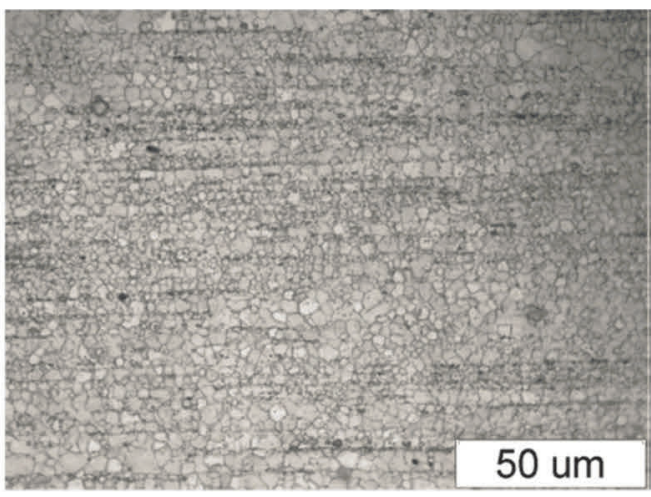

c)
AZ61

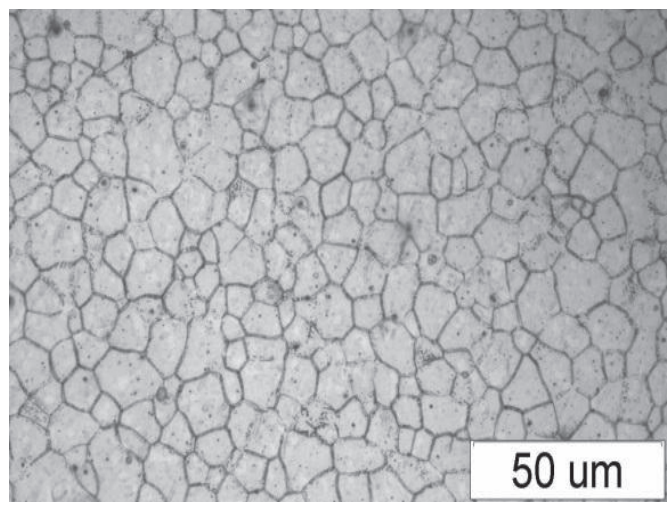

b)

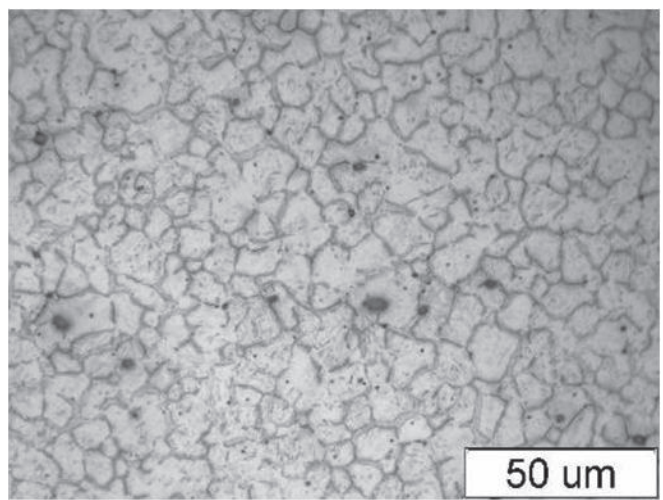

d)

Figure 3 Microstructure magnesium alloys after extrusion of method KoBo: a-b) rods with diameter of $\phi 8$ $\mathrm{mm}, \mathrm{C}-\mathrm{d}$ ) rods with diameter of $\phi 6 \mathrm{~mm}$

Table 2 Results of quantitative characterization AZ61

\begin{tabular}{|c|c|c|c|}
\hline $\begin{array}{c}\text { Alloy } \\
\text { AZ61 }\end{array}$ & $\begin{array}{c}\text { Average equivalent diameter of grains } \\
(\mu \mathrm{m})\end{array}$ & $\begin{array}{c}\text { Average surface area } \\
\left(\mu \mathrm{m}^{2}\right)\end{array}$ & Shape factor \\
\hline after casting & 27 & 97 & 0.67 \\
\hline $\begin{array}{c}\text { after cold extrusion by KoBo method } \\
\text { rods with diameter of } \phi 8 \mathrm{~mm}\end{array}$ & 20 & 96 & 0.73 \\
\hline $\begin{array}{c}\text { after cold extrusion by KoBo method } \\
\text { rods with diameter of } \phi 6 \mathrm{~mm}\end{array}$ & 10 & 30 & 0.70 \\
\hline
\end{tabular}

Table 3 Results of quantitative characterization WE43

\begin{tabular}{|c|c|c|c|}
\hline $\begin{array}{c}\text { Alloy } \\
\text { WE43 }\end{array}$ & $\begin{array}{c}\text { Average equivalent diameter of grains } \\
(\mu \mathrm{m})\end{array}$ & $\begin{array}{c}\text { Average surface area } \\
\left(\mu \mathrm{m}^{2}\right)\end{array}$ & Shape factor \\
\hline after casting & 70 & 99 & 0.73 \\
\hline $\begin{array}{c}\text { after cold extrusion by KoBo method } \\
\text { rods with diameter of } \phi 8 \mathrm{~mm}\end{array}$ & 55 & 94 & 0.67 \\
\hline $\begin{array}{c}\text { after cold extrusion by KoBo method } \\
\text { rods with diameter of } \phi 6 \mathrm{~mm}\end{array}$ & 1 & 0.51 & 0.53 \\
\hline
\end{tabular}

Samples for tests of mechanical properties in temperature RT and in elevated temperature $\left(300{ }^{\circ} \mathrm{C}, 350{ }^{\circ} \mathrm{C}\right)$ were taken from achieved rods with diameter of $6 \mathrm{~mm}$ from alloys WE43 and AZ61. Results of mechanical properties after tension tests for alloys AZ61, WE43 determined in room temperature (RT), $300{ }^{\circ} \mathrm{C}, 350{ }^{\circ} \mathrm{C}$ are 
shown in Table 2 and Figure 3. There were more beneficial properties achieved for samples deformed with the use of KoBo method. There was an effect of superplastic flow observed in $350{ }^{\circ} \mathrm{C}$. The value of elongation equalled $250 \%$ (WE43), $300 \%$ (AZ61) (Table 4).

Table 4 Results of tensile testing at the tested alloys and increased $\mathrm{RT}, 300^{\circ} \mathrm{C}, 350^{\circ} \mathrm{C}$ after method KoBo

\begin{tabular}{|c|c|c|c|c|c|c|}
\hline \multirow{2}{*}{ Alloy } & \multicolumn{3}{|c|}{ Stress (MPa) } & \multicolumn{3}{c|}{ Elongation (\%) } \\
\cline { 2 - 7 } & RT & $300^{\circ} \mathrm{C}$ & $350^{\circ} \mathrm{C}$ & RT & $300^{\circ} \mathrm{C}$ & $350{ }^{\circ} \mathrm{C}$ \\
\hline WE43 & 265 & 108 & 40 & 24 & 85 & 250 \\
\hline AZ61 & 309 & 53 & 22 & 15 & 169 & 300 \\
\hline
\end{tabular}
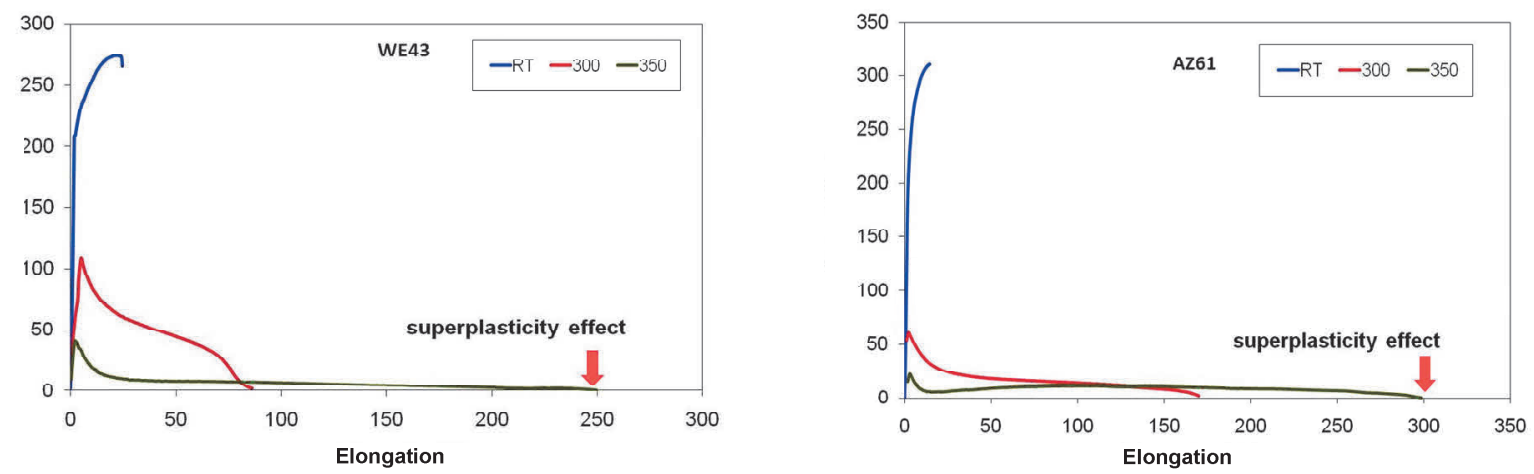

Figure 4 Results of static tensile tests in temperature RT, $300{ }^{\circ} \mathrm{C}, 350{ }^{\circ} \mathrm{C}$ : a) WE43, b) AZ61

\section{CONCLUSION}

Achieved tests results show good susceptibility to cold shaping of alloys AZ61, WE43 in extrusion process with the use of KoBo method which is not possible in conventional processes of plastic shaping which require elevated temperature in the range of $300{ }^{\circ} \mathrm{C}-400{ }^{\circ} \mathrm{C}$. As a result of the applied process of extrusion the refinement of microstructure of tested alloys was achieved. The most favourable results were achieved for alloy WE43. Achieved microstructure of tested alloys after extrusion process should provide good mechanical properties during their further shaping in elevated temperature. Results of conducted tension tests in room temperature and elevated temperature of $300^{\circ} \mathrm{C}, 350^{\circ} \mathrm{C}$ show that the tested alloys have beneficial resistance properties and plastic properties. The effect of superplastic flow after extrusion with KoBo method was found due to the conducted mechanical tests. The value of elongation in temperature of $350^{\circ} \mathrm{C}$ equalled about 250 $\%$ (WE43) and $300 \%$ (AZ61). Cold forming aided by additional shear stress can be applied as an alternative method for obtaining products of required density and strength. Presented results of tests will become the basis to conduct further tests in order to prepare technologies of metalforming of magnesium alloys with the use of unconventional methods of deformation.

\section{ACKNOWLEDGEMENTS}

The work was supported by the Ministry of Science and Higher Education within the framework of the BK-205/RM0/2019.

\section{REFERENCE}

[1] RUDOLF K., Magnez i stopy magnezu. Praca zbiorowa pod redakcją Hadasik Eugeniusz. Przetwórstwo metali. Plastyczność a struktura. Wydawnictwo Politechniki Śląskiej, Gliwice 2006. 
[2] KURZYDŁOWSKI K., LEWANDOWSKA M. Nanomateriały Inżynierskie Konstrukcyjne i Funkcjonalne, Wydawnictwo Naukowe PWN.

[3] KORBEL A., BOCHNIAK W., OSTACHOWSKI P., PALIBOREK A. Mechanical properties of aluminum extruded by KOBO method with direct and lateral outflow. International Journal of Materials Research 102 (10) 2013 pp $974-$ 79.

[4] BOCHNIAK W., Teoretyczne i praktyczne aspekty plastycznego kształtowania metali, metoda KoBo, AGH Kraków 2009.

[5] BOCHNIAK W., KORBEL A., OSTACHOWSKI P., ZIÓŁKIEWICZ S., BOROWSKI J. Wyciskanie metali i stopów metodą KOBO, Obróbka Plastyczna Metali 2 (2013), XXIV, pp. 83-97.

[6] CHENG-CHENG Z., HUI-YUAN W., MIN Z., CHENG W., JIE-HUA LI, ZHI-ZHENG Y., AND QI-CHUAN J., Microstructure and Tensile Properties of AZ61 Alloy Sheets Processed by High-Ratio Extrusion with Subsequent Direct Aging Treatment, Materials, 11(6), 2018, pp 895.

[7] SHENG K, LI-WEI L., YAO XIANG M., ZHONG-CHANG W. Microstructure and mechanical properties of AZ31 Mg alloy fabricated by pre-compression and frustum shearing extrusion, Acta Metallurgica Sinica 32, (2019), pp. 235244.

[8] SZALA J., Application of computer picture analysis methods to quantitative assessment of structure in materials, Scientific Journals of Silesian University of Technology, Series Metallurgy, Gliwice, 2008.

[9] BEDNARCZYK I., KUC D., TOMASZEWSKA A., MRUGAŁA A. The influence of extrusion process on the microstructure and mechanical properties of magnesium alloys, Archives of Metallurgy and Materials, 62 (2017), 2 , pp. 545-550.

[10] RODAK K., Structure and mechanical properties of the $\mathrm{Cu}$ and Al forming by compression with oscillatory torsion metod, Monograph of Silesian University of Technology, Gliwice, 2012.

[11] KOWALCZYK. K., JABŁOŃSKA M., RUSZ S., BEDNARCZYK I. Drece prcess of severe plastic deformation on the mechanical properties of the ultra-low carbon interstitial free steel - Archives of Metallurgy and Materials 63 (2018), 4, pp. 2095-2100 